\title{
先発医薬品と後発医薬品の剤形類似性の検討
}

\author{
庄野文章 ${ }^{* 1}$, 日浦田崇紘 ${ }^{1}$, 前田恵里 ${ }^{1}$, 原田香穂里 ${ }^{1}$ \\ 土井沙由梨 ${ }^{1}$, 富田かおり ${ }^{1}$, 土屋浩一郎 ${ }^{2}$ \\ 徳島文理大学薬学部医療薬学講座 ${ }^{1}$, 徳島大学大学院ヘルスバイオサイエンス研究部医薬品機能生化学分野 ${ }^{2}$
}

\section{Consideration of the Visual Resemblance between Original and Generic Drugs}

\author{
Fumiaki Shono ${ }^{* 1}$, Takahiro Hiurata ${ }^{1}$, Eri Maeda ${ }^{1}$, Kaori Harada ${ }^{1}$, \\ Sayuri Doi ${ }^{1}$, Kaori Tomita ${ }^{1}$ and Koichiro Tsuchiya ${ }^{2}$ \\ Department of Clinical Pharmacy, Faculty of Pharmaceutical Sciences, Tokushima Bunri University ${ }^{1}$, \\ Department of Medical Pharmacology, Institute of Health Biosciences, the University of Tokushima Graduate School ${ }^{2}$
}

\footnotetext{
$\left[\begin{array}{l}\text { Received November 26, } 2012 \\ \text { Accepted March 19, } 2013\end{array}\right]$
}

Generic medicines are often put on the market with shapes and PTP packaging similar to those of the original drugs, which may cause preparation and medication errors. However, there has been no comparative study on the visual resemblance between original and generic drugs. We extracted eight items related to the similarity in appearance from their interview forms, and compared them using the cluster analysis method.

According to the results, most generic drugs converged in the same group as their originals, while a few of them were classified into different groups.

In addition, there was no relationship between the result of the cluster analysis and their therapeutic classes, and no apparent intention of manufacturers to give a similar appearance to their generic products.

Our findings demonstrate the effectiveness and applicability of cluster analysis for drug classification by resemblance.

Key words — original drug, generic drug, visual resemblance between drugs, cluster analysis, interview form

\section{諸言}

後発医薬品の使用環境の拡大と促進政策によ り，平成 24 年 3 月厚生労働省は条件付きで，異 なる含量規格および類似する別剤形への変更を可 能としたことで，さらに後発医薬品使用の機会が 増えることが予想される。後発医薬品の普及は患 者負担の軽減や医療保険財政の改善に結びつく が，その反面，医療従事者や患者の医薬品に対す る情報伝達等に影響を及ぼし適正な使用が難しく なることも予想される. 厚生労働省は後発医薬品 の使用促進のため後発医薬品調剂体制加算の見直 し, 後発医薬品に関する情報提供の薬剤服用歴管 理指導料への算定等, 様々な施策を行うとともに,
後発医薬品の品質確保を目指し独立行政法人 ・医 薬品医療機器総合機構内にジェネリック医薬品品 質情報検討会を設けている（http://www.info. pmda.go.jp/generic/generic_index.html).ところで, 従来から先発医薬品に剂形やPTP 包装形態を類 似させた後発医薬品は市販されており，外観類似 性による調剤ミスや服薬ミスへの懸念が報告され

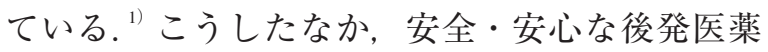
品の使用促進を目指して製薬企業では先発医薬品 との PTP 包装の識別性は勿論のこと, 一包化調 剂時の過誤防止や錠剂鑑別時の作業軽減から色, 大きさ，刻印などの違いにより識別が可能な製剤 の開発が進められている.さらに厚生労働省が「医 療用医薬品へのバーコード表示の実施要項」 ${ }^{2)}$

*徳島県徳島市山城町西浜傍示 180 
示したことから, 将来的に医薬品の取り違え事故 の防止が進むと考えられている.

ところで，患者がどのような方法で服用時に医 薬品を識別しているかについて調査した結果によ ると,「PTP 包装の外観のみ」 $(46.5 \%)$ に続いて 「薬本体の外観のみ」(18.7\%)「 ГPTP 包装の外観 + 薬本体の外観」 $(13.5 \%)$, 「薬の名称のみ」 （9.7\%）の順であった。また「薬本体の外観のみ」 で識別しているのは 60 歳代以上の患者で多かっ

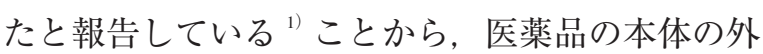
観が識別に関する大きな因子となっていることが 伺えた.このことは, 特に高齢者の患者において 先発医薬品から後発医薬品への変更に打ける医薬 品の外観の類似性も, 薬局からの情報提供の重要 な要素になり得ることを意味している。しかし， 後発医薬品の医薬品本体等の外観についてどの程 度先発医薬品と類似しているかを比較調查した報 告は見当たらない. そこで, 先発医薬品と後発医 薬品の剂形の類似性の現状について医薬品インタ ビューフォーム (IF) で確認できる項目を抽出し, 類似性扔よびその程度を分析する手法としてクラ スター解析を用い 12 成分 219 品目を検討したと ころ，類似性において分類することができたので 報告する．

\section{方 法}

\section{1. 先発医薬品と後発医薬品の外観調査}

調查品目は 12 成分（表 1）の先発医薬品と後 発医薬品（先発医薬品 14 品目, 後発医薬品 205 品目, 合計 219 品目) について, 製薬会社から提 供されている IF を基に形状, 色, 刻印, 割線の 有無, 面積, 厚さ, 質量の各調査項目について集 計した．表 2 にはブロチゾラムの例を示す.

\section{2. クラスター分析}

クラスター分析とは, 異なる性質のものが混ざ り合っている集団（対象）のなかから，1つ以上 の因子に着目し互いに似たものを集めて集落（ク ラスター）をつくり，対象を分類しようという方 法を総称したもので, その応用範囲は広く, 遺伝 子工学や電気工学, ${ }^{3}$ 農学分野 ${ }^{4)}$ でグループ分け
を行うときに沉用されている. 先発医薬品と後発 医薬品の剤形がどのようなクラスターにグループ 分けされるかを検討する目的で階層的クラスタリ ング法を用い, かつ分類感度が高いと言われてい るWard 法により，以下のように応用を試みた。

表 2 について徳島文理大学薬学部の健康な学 生 5 名（23〜27歳, 男 1 名, 女 4 名）により IF から収集可能でかつヒトの視覚, 感覚で認知可能 な 8 項目 (形状, 色, 表刻印, 裏刻印, 割線, 面 積, 厚さ, 質量) について検討した. またクラス ター分析（Ward 法）を用いるため, 以下に示す ように視覚でも判断が容易な「形状」や「色」は 基準として 2 倍の係数,「面積」「「厚さ」,「質量」 は $20 \%$ 以上の変動で 0.5 倍, その他の項目は先発 医薬品と同様の場合 1 , 違う場合 0 として以下の 8 種の指標を用いて判別性を数值化した.

A 先発医薬品の形状 $=2$ として, 後発医薬品が 違う形なら 1 にする。（2 倍值）

$\mathrm{B}$ 先発医薬品の色 $=2$ として, 後発医薬品が違 う色なら 1 にする。（2 倍值）

$\mathrm{C}$ 表刻印 先発医薬品と同様 $=1$, 違う $=0$

$\mathrm{D}$ 裏刻印 先発医薬品と同様 $=1$, 違う $=0$

$\mathrm{E}$ 割線 先発医薬品と同様 $=1$, 違う $=0$

$\mathrm{F}$ 面積 $\left(\pi \mathrm{r}^{2}\right)$ 先発医薬品と同様 $=1$, $20 \%$ 増又は減 $=0.5$

$\mathrm{G}$ 厚さ $(\mathrm{mm})$ 先発医薬品と同様 $=1$, $20 \%$ 増又は減 $=0.5$

$\mathrm{H}$ 質量 $(\mathrm{mg})$ 先発医薬品と同様 $=1$, $20 \%$ 増又は減 $=0.5$

このように, 重み付けにより得られた集計結果 （表 2）に対し，ユークリッド平方距離により非 類似度を算出し, 得られた值を用いてクラスター 分析（Ward 法）により解析を行った.

\section{結果}

\section{1. 目視と IF による分類と先発医薬品と後発医 薬品の類似性の検討}

錠剤の外観 (形状, 色, 刻印, 割線の有無, 面 積, 厚さ, 質量） 8 項目について著者らが目視と IF を基に分類と類似性の検討を行った. 
表 112 成分の先発品および後発品会社リスト

\begin{tabular}{|c|c|c|c|c|c|}
\hline $\begin{array}{l}\text { アムロジピン錠 } \\
2.5 \mathrm{mg}\end{array}$ & $\begin{array}{l}\text { エナラプリルマレイ } \\
\text { ン酸塩 } 10 \mathrm{mg}\end{array}$ & $\begin{array}{l}\text { クラリスロマイシン } \\
\text { 錠 } 200 \text { mg }\end{array}$ & $\begin{array}{l}\text { シロスタゾール錠 } \\
100 \mathrm{mg}\end{array}$ & $\begin{array}{l}\text { ドネペジル塩酸塩錠 } \\
5 \mathrm{mg}\end{array}$ & $\begin{array}{l}\text { トリアゾラム } \\
0.25 \mathrm{mg} \text { 錠 }\end{array}$ \\
\hline ファイザー & MSD & アボット & 大塚製薬 & エーザイ & ファイザー \\
\hline 大日本住友 & テバ製薬 & 大正製薬 & 東和薬品 & 大日本住友製薬 & サンノーバ \\
\hline 日医工ファーマ & 小林化工 & 東和薬品 & テバ製薬 & 富士フイルムファーマ & 辰巳化学 \\
\hline エルメッドエーザイ & 日新製薬 & ニプロファーマ & 沢井薬品 & 日本ジェネリック & 長生堂製薬 \\
\hline 鶴原製薬 & 辰巳化学 & キョーリンリメディオ & 日医工 & 共和薬品工業 & 日新製薬 \\
\hline 小林化工 & 共和薬品工業 & 長生堂製薬 & 大正薬品工業 & 日本ケミファ & 小林化工 \\
\hline 東和薬品 & ダイト & サンド & 旭化成ファーマ & 鶴原製薬 & 大興製薬 \\
\hline ザイダスファーマ & 日本ジェネリック & 田辺三菱製薬 & 陽進堂 & サンド & 日医工 \\
\hline 第一三共エスファ & サンド & メディサ新薬 & ファイザー & テバ製薬 & テバ製薬 \\
\hline キョーリンリメディオ & マイラン製薬 & マイラン & 寿製薬 & 田辺三菱製薬 & 鶴原製薬 \\
\hline ビオメディクス & メディサ新薬 & 小林化工 & 日本薬品工業 & 東和薬品 & 寿製薬 \\
\hline 共和薬品工業 & 沢井製薬 & シオノケミカル & 大原薬品工業 & マイラン & 富士薬品 \\
\hline 日医工ファーマ & ジェイドルフ製薬 & 大正薬品工業 & サンド & キョーリンメデイオ & \\
\hline 大興製薬 & 長生堂製薬 & テバ製薬 & 高田製薬 & シオノケミカル & \\
\hline 日本薬品工業 & 大原薬品工業 & 沢井薬品 & 長生堂製薬 & 大正薬品工業 & \\
\hline 日新製薬 & 東和薬品 & 日医工 & マイラン & 日医工 & \\
\hline 長生堂製薬 & 日医工 & 辰巳化学 & ニプロファーマ & MeijiSeika ファルマ & \\
\hline 田辺三菱製薬 & 日本薬品工業 & 日本薬品工業 & 小林化工 & 辰巳化学 & \\
\hline シオノケミカル & & 高田製薬 & シオノケミカル & ニプロファーマ & \\
\hline 大原薬品工業 & & & ダイト & 沢井製薬 & \\
\hline メディサ新薬 & & & 日本ジェネリック & 高田製薬 & \\
\hline マイラン製薬 & & & & 日新製薬 & \\
\hline サンド & & & & ビオメディクス & \\
\hline 富士製薬工業 & & & & 第一三共エスファ & \\
\hline ニプロファーマ & & & & 陽進堂 & \\
\hline 陽進堂 & & & & 大原薬品工業 & \\
\hline \multicolumn{6}{|l|}{ 日本ジェネリック } \\
\hline \\
\hline \multicolumn{6}{|l|}{$\begin{array}{l}\text { 日医工 } \\
\text { 唇巳化学 }\end{array}$} \\
\hline \multicolumn{6}{|l|}{ 辰巳化学 } \\
\hline \multicolumn{6}{|l|}{ あすか製薬 } \\
\hline 沢井製薬 & & & & & \\
\hline 救急薬品工券 & & & & & \\
\hline
\end{tabular}

\begin{tabular}{|c|c|c|c|c|c|}
\hline \multirow{2}{*}{$\begin{array}{l}\text { アトルバスタチン } \\
10 \mathrm{mg}\end{array}$} & レバミピド & \multirow{2}{*}{$\begin{array}{l}\text { ノルフロキサシン錠 } \\
200 \mathrm{mg} \\
\end{array}$} & \multirow{2}{*}{$\begin{array}{l}\text { チクロピジン塩酸塩 } \\
\text { 錠 } 100 \text { mg }\end{array}$} & \multirow{2}{*}{$\begin{array}{l}\text { ブロチゾラム } \\
\text { Boehringerlngelheim }\end{array}$} & \multirow{3}{*}{$\begin{array}{l}\text { ロラタジン } \\
\text { MSD }\end{array}$} \\
\hline & \multirow{2}{*}{$\begin{array}{l}\text { 大塚製薬 } \\
\text { 大興製薬 }\end{array}$} & & & & \\
\hline アステラス & & 杏林製薬 & サノフィアベンティス & 東和薬品 & \\
\hline 東和薬品 & 日本ジェネリック & エルメッドエーザイ & 東和薬品 & テバ製薬 & エルメッドエーザイ \\
\hline サンド & 寿製薬 & サンノーバ & テバ製薬 & メディサ新薬 & 富士フイルムファーマ \\
\hline 沢井薬品 & メディサ新薬 & 沢井薬品 & メデイサ新薬 & 日医工 & 日本ジェネリック \\
\hline エルメッドエーザイ & ニプロファーマ & イセイ & 日医工 & 辰巳化学 & ニプロファーマ \\
\hline \multirow[t]{19}{*}{ 小林化工 } & シオノケミカル & 辰巳化学 & 小林化工 & 陽進堂 & 陽進堂 \\
\hline & 鶴原製薬 & 陽進堂 & 辰巳化学 & 日新製薬 & 共和薬品工業 \\
\hline & 大正薬品工業 & 鶴原製薬 & 陽進堂 & 共和薬品工業 & ダイト \\
\hline & 全星薬品工業 & 全星薬品工業 & 鶴原製薬 & 大原薬品工業 & 沢井製薬 \\
\hline & キョーリンリメディオ & & サンド & 長生堂製薬 & 長生堂製薬 \\
\hline & 日新製薬 & & キョーリンメディオ & マイラン製薬 & ファイザー \\
\hline & 陽進堂 & & 三和化学 & 大正薬品工業 & テバ製薬 \\
\hline & あすか製薬 & & ニプロファーマ & 田辺三菱製薬 & 日医工 \\
\hline & 共和薬品工業 & & 日新製薬 & アルフレッサファーマ & 日新製薬 \\
\hline & 日本ケミファ & & & 大興製薬 & 辰巳化学 \\
\hline & 沢井製薬 & & & ニプロファーマ & 小林化工 \\
\hline & 田辺三菱製薬 & & & & \\
\hline & 東和薬品 & & & & \\
\hline & ファイザー & & & & \\
\hline & マイラン製薬 & & & & \\
\hline & 日医工 & & & & \\
\hline & MeijiSeika ファルマ & & & & \\
\hline & 辰巳化学 & & & & \\
\hline & 大原薬品工業 & & & & \\
\hline *太字は成分名 & 日本薬品工業 & & & & \\
\hline および先発会社 & 高田製薬 & & & & \\
\hline
\end{tabular}


ブロチゾラム製剤の先発品と後発品の外観調査と数值化

\begin{tabular}{|c|c|c|c|c|c|c|c|c|c|c|c|c|}
\hline & & & 形状 & $\begin{array}{l}\text { 表面 } \\
\text { 色調 }\end{array}$ & & 刻印 & • 割線の & 有無 & 直径 & $\begin{array}{l}\text { 表面積 } \\
(\mathrm{F})^{*}\end{array}$ & $\begin{array}{l}\text { 厚さ } \\
(\mathrm{G})^{*}\end{array}$ & $\begin{array}{l}\text { 質量 } \\
(\mathrm{H})^{*}\end{array}$ \\
\hline & 会社名 & 商品名 & $\begin{array}{l}\text { 形状 } \\
(\mathrm{A})^{*}\end{array}$ & 表面 & (B) & $\begin{array}{l}\text { 刻印表 } \\
(\mathrm{C})^{*}\end{array}$ & $\begin{array}{l}\text { 刻印裏 } \\
(\mathrm{D})^{*}\end{array}$ & $\begin{array}{l}\text { 割線 } \\
(\mathrm{E})^{*}\end{array}$ & $(\mathrm{~mm})$ & $\left(\mathrm{mm}^{2}\right)$ & $(\mathrm{mm})$ & $(\mathrm{mg})$ \\
\hline $\begin{array}{l}\text { 先 } \\
\text { 発 }\end{array}$ & BoehringerIngelheim & $\begin{array}{l}\text { レンドルミン錠 } \\
0.25 \mathrm{mg}\end{array}$ & $\begin{array}{l}\text { 丸 } \\
(2)\end{array}$ & 素錠 & $\begin{array}{l}\text { 白 } \\
(2)\end{array}$ & $\begin{array}{l}\bigcirc \\
(1)\end{array}$ & $\begin{array}{l}\bigcirc \\
(1)\end{array}$ & $\begin{array}{l}\bigcirc \\
(1)\end{array}$ & 8 & $\begin{array}{l}16 \pi \\
(1)\end{array}$ & $\begin{array}{l}2.5 \\
(1)\end{array}$ & $\begin{array}{c}150 \\
(1)\end{array}$ \\
\hline & 東和薬品 & $\begin{array}{l}\text { ゼストロミン錠 } \\
0.25 \mathrm{mg}\end{array}$ & $\begin{array}{l}\text { 丸 } \\
\text { (2) }\end{array}$ & 素錠 & $\begin{array}{l}\text { 白 } \\
(2)\end{array}$ & $\begin{array}{l}\bigcirc \\
(1)\end{array}$ & $\begin{array}{l}\times \\
(0)\end{array}$ & $\begin{array}{l}\bigcirc \\
(1)\end{array}$ & 8 & $\begin{array}{l}16 \pi \\
(1)\end{array}$ & $\begin{array}{l}2.4 \\
(1)\end{array}$ & $\begin{array}{c}150 \\
(1)\end{array}$ \\
\hline & テバ製薬 & $\begin{array}{l}\text { ブロチゾラム錠 } \\
0.25 \mathrm{mg}\lceil\text { タイヨー」 }\end{array}$ & $\begin{array}{l}\text { 丸 } \\
\text { (2) }\end{array}$ & 素錠 & $\begin{array}{l}\text { 白 } \\
(2)\end{array}$ & $\stackrel{\bigcirc}{(1)}$ & $\begin{array}{l}\times \\
(0)\end{array}$ & $\begin{array}{l}\bigcirc \\
(1)\end{array}$ & 8 & $\begin{array}{l}16 \pi \\
(1)\end{array}$ & $\begin{array}{l}2.4 \\
(1)\end{array}$ & $\begin{array}{c}160 \\
(1)\end{array}$ \\
\hline & メディサ新薬 & $\begin{array}{l}\text { レンデム錠 } \\
0.25 \mathrm{mg}\end{array}$ & $\begin{array}{l}\text { 丸 } \\
\text { (2) }\end{array}$ & 素錠 & $\begin{array}{l}\text { 白 } \\
(2)\end{array}$ & $\stackrel{\bigcirc}{(1)}$ & $\begin{array}{l}\times \\
(0)\end{array}$ & $\stackrel{\bigcirc}{(1)}$ & 8 & $\begin{array}{l}16 \pi \\
(1)\end{array}$ & $\begin{array}{l}2.8 \\
(1)\end{array}$ & $\begin{array}{l}\text { 約 } 175 \\
\text { (1) }\end{array}$ \\
\hline & 日医工 & $\begin{array}{l}\text { ブロチゾラン錠 } \\
0.25 \mathrm{mg}\end{array}$ & $\begin{array}{l}\text { 丸 } \\
(2)\end{array}$ & 素錠 & $\begin{array}{l}\text { 白 } \\
(2)\end{array}$ & (1) & $\begin{array}{l}\times \\
(0)\end{array}$ & $\begin{array}{l}0 \\
(1)\end{array}$ & 7 & $\begin{array}{l}12 \pi \\
(0.5)\end{array}$ & $\begin{array}{l}2.5 \\
(1)\end{array}$ & $\begin{array}{r}120 \\
(1)\end{array}$ \\
\hline & 辰巳化学 & $\begin{array}{l}\text { ネストローム錠 } \\
0.25 \mathrm{mg}\end{array}$ & $\begin{array}{l}\text { 丸 } \\
(2)\end{array}$ & 素錠 & $\begin{array}{l}\text { 白 } \\
(2)\end{array}$ & $\begin{array}{l}\bigcirc \\
(1)\end{array}$ & $\begin{array}{l}\times \\
(0)\end{array}$ & $\begin{array}{l}\bigcirc \\
(1)\end{array}$ & 7.1 & $\begin{array}{l}13 \pi \\
(0.5)\end{array}$ & $\begin{array}{l}2.3 \\
(1)\end{array}$ & $\begin{array}{c}120 \\
(1)\end{array}$ \\
\hline & 陽進堂 & $\begin{array}{l}\text { ブロチゾラム錠 } \\
0.25 \mathrm{mg} 「 \mathrm{YD}\rfloor\end{array}$ & $\begin{array}{l}\text { 丸 } \\
\text { (2) }\end{array}$ & 素錠 & $\begin{array}{l}\text { 白 } \\
(2)\end{array}$ & $\begin{array}{l}\bigcirc \\
(1)\end{array}$ & $\begin{array}{l}\times \\
(0)\end{array}$ & $\begin{array}{l}\bigcirc \\
(1)\end{array}$ & 約 8 & $\begin{array}{l}16 \pi \\
(1)\end{array}$ & $\begin{array}{l}\text { 約 } 2.4 \\
\text { (1) }\end{array}$ & $\begin{array}{c}150 \\
(1)\end{array}$ \\
\hline & 日新製薬 & $\begin{array}{l}\text { アムネゾン錠 } \\
0.25 \mathrm{mg}\end{array}$ & $\begin{array}{l}\text { 楕円 } \\
\text { (1) }\end{array}$ & 裸錠 & $\begin{array}{l}\text { 白 } \\
(2)\end{array}$ & $\begin{array}{l}\bigcirc \\
(1)\end{array}$ & $\begin{array}{l}\times \\
(0)\end{array}$ & $\begin{array}{l}\times \\
(0)\end{array}$ & $\begin{array}{l}\text { 長径 } 10 \\
\text { 短径 } 6.5\end{array}$ & $\begin{array}{l}16 \pi \\
(1)\end{array}$ & $\begin{array}{l}2.8 \\
(1)\end{array}$ & $\begin{array}{c}170 \\
(1)\end{array}$ \\
\hline 後 & 共和薬品工業 & $\begin{array}{l}\text { ロンフルマン錠 } \\
0.25 \mathrm{mg}\end{array}$ & $\begin{array}{l}\text { 丸 } \\
\text { (2) }\end{array}$ & 素錠 & $\begin{array}{l}\text { 白 } \\
(2)\end{array}$ & $\begin{array}{l}\bigcirc \\
(1)\end{array}$ & $\begin{array}{l}\times \\
(0)\end{array}$ & $\begin{array}{l}\bigcirc \\
(1)\end{array}$ & 6 & $\begin{array}{l}9 \pi \\
(0.5)\end{array}$ & $\begin{array}{l}2.1 \\
(1)\end{array}$ & $\begin{array}{l}80 \\
(0.5)\end{array}$ \\
\hline . & 大原薬品工業 & $\begin{array}{l}\text { レドルパー錠 } \\
0.25 \mathrm{mg}\end{array}$ & $\begin{array}{l}\text { 丸 } \\
(2)\end{array}$ & 素錠 & $\begin{array}{l}\text { 白 } \\
(2)\end{array}$ & $\begin{array}{l}\bigcirc \\
(1)\end{array}$ & $\begin{array}{c}\times \\
(0)\end{array}$ & (1) & 8 & $\begin{array}{l}16 \pi \\
(1)\end{array}$ & $\begin{array}{l}2.3 \\
(1)\end{array}$ & $\begin{array}{l}150 \\
(1)\end{array}$ \\
\hline & 長生堂製薬 & $\begin{array}{l}\text { ブロチゾラム錠 } \\
0.25 \mathrm{mg} 「 \mathrm{CH}\rfloor\end{array}$ & $\begin{array}{l}\text { 丸 } \\
(2)\end{array}$ & 素錠 & $\begin{array}{l}\text { 白 } \\
(2)\end{array}$ & $\begin{array}{l}\bigcirc \\
(1)\end{array}$ & $\begin{array}{l}\times \\
(0)\end{array}$ & $\begin{array}{l}\bigcirc \\
(1)\end{array}$ & 8 & $\begin{array}{l}16 \pi \\
(1)\end{array}$ & $\begin{array}{l}2.4 \\
(1)\end{array}$ & $\begin{array}{c}150 \\
(1)\end{array}$ \\
\hline & マイラン製薬 & $\begin{array}{l}\text { ブロメトン錠 } \\
0.25 \mathrm{mg}\end{array}$ & $\begin{array}{l}\text { 丸 } \\
(2)\end{array}$ & 素錠 & $\begin{array}{l}\text { 白 } \\
(2)\end{array}$ & $\begin{array}{l}0 \\
(1)\end{array}$ & $\begin{array}{l}\times \\
(0)\end{array}$ & $\begin{array}{l}\bigcirc \\
(1)\end{array}$ & 7 & $\begin{array}{l}12 \pi \\
(0.5)\end{array}$ & $\begin{array}{l}3.1 \\
(0.5)\end{array}$ & $\begin{array}{r}120 \\
(1)\end{array}$ \\
\hline & 大正薬品工業 & $\begin{array}{l}\text { ソレントミン錠 } \\
0.25 \mathrm{mg}\end{array}$ & $\begin{array}{l}\text { 丸 } \\
\text { (2) }\end{array}$ & 素錠 & $\begin{array}{l}\text { 白 } \\
(2)\end{array}$ & $\begin{array}{l}\bigcirc \\
(1)\end{array}$ & $\begin{array}{l}\times \\
(0)\end{array}$ & $\begin{array}{l}\bigcirc \\
(1)\end{array}$ & 8 & $\begin{array}{l}16 \pi \\
(1)\end{array}$ & $\begin{array}{l}2.3 \\
(1)\end{array}$ & $\begin{array}{l}\text { 約 } 150 \\
\text { (1) }\end{array}$ \\
\hline & 田辺三菱製薬 & $\begin{array}{l}\text { グッドミン錠 } \\
0.25 \mathrm{mg}\end{array}$ & $\begin{array}{l}\text { 丸 } \\
\text { (2) }\end{array}$ & 素錠 & $\begin{array}{l}\text { 白 } \\
\text { (2) }\end{array}$ & $\begin{array}{l}\bigcirc \\
(1)\end{array}$ & $\begin{array}{l}\times \\
(0)\end{array}$ & $\begin{array}{l}\bigcirc \\
(1)\end{array}$ & 8 & $\begin{array}{l}16 \pi \\
(1)\end{array}$ & $\begin{array}{l}2.4 \\
(1)\end{array}$ & $\begin{array}{c}150 \\
(1)\end{array}$ \\
\hline & $\begin{array}{l}\text { アルフレッサ } \\
\text { ファーマ }\end{array}$ & $\begin{array}{l}\text { ノクスタール錠 } \\
0.25 \mathrm{mg}\end{array}$ & $\begin{array}{l}\text { 丸 } \\
\text { (2) }\end{array}$ & 素錠 & $\begin{array}{l}\text { 白 } \\
\text { (2) }\end{array}$ & $\begin{array}{l}\bigcirc \\
(1)\end{array}$ & $\begin{array}{l}\times \\
(0)\end{array}$ & $\begin{array}{l}\bigcirc \\
(1)\end{array}$ & 8 & $\begin{array}{l}16 \pi \\
(1)\end{array}$ & $\begin{array}{l}2.3 \\
(1)\end{array}$ & $\begin{array}{c}150 \\
(1)\end{array}$ \\
\hline & 大興製薬 & $\begin{array}{l}\text { ブロチゾラム錠 } \\
0.25 \mathrm{mg}\lceil\mathrm{JG} 」\end{array}$ & $\begin{array}{l}\text { 丸 } \\
(2)\end{array}$ & 素錠 & $\begin{array}{l}\text { 白 } \\
\text { (2) }\end{array}$ & $\begin{array}{l}\bigcirc \\
(1)\end{array}$ & $\begin{array}{c}\times \\
(0)\end{array}$ & $\begin{array}{l}\bigcirc \\
(1)\end{array}$ & 8 & $\begin{array}{l}16 \pi \\
(1)\end{array}$ & $\begin{array}{l}2.4 \\
(1)\end{array}$ & $\begin{array}{c}160 \\
(1)\end{array}$ \\
\hline & ニプロファーマ & $\begin{array}{l}\text { ブロゾーム錠 } \\
0.25 \mathrm{mg}\end{array}$ & $\begin{array}{l}\text { 丸 } \\
(2)\end{array}$ & 素錠 & $\begin{array}{l}\text { 白 } \\
(2)\end{array}$ & $\stackrel{\bigcirc}{(1)}$ & $\begin{array}{l}\times \\
(0)\end{array}$ & $\stackrel{\bigcirc}{(1)}$ & 8 & $\begin{array}{l}16 \pi \\
(1)\end{array}$ & $\begin{array}{l}2.3 \\
(1)\end{array}$ & $\begin{array}{c}150 \\
(1)\end{array}$ \\
\hline
\end{tabular}

${ }^{*} \mathrm{~A}$ 先発品の形状 $($ 丸 $)=2$ ( 2 倍值) として, 後発品が違う形なら 1 にする

* $\mathrm{B}$ 先発品の色 $($ 白 $)=2$ (2 倍值) として, 後発品が違う色なら 1 にする

${ }^{*} \mathrm{C}$ 表刻印 先発品と同様 (刻印有り) $=1$, 違う (刻印無し) $=0$

${ }^{*} \mathrm{D}$ 裏刻印 先発品と同様 (刻印有り) $=1$, 違う (刻印無し) $=0$

${ }^{*} \mathrm{E}$ 割線 先発品と同様 $($ 割線有り $)=1$, 違う (割線無し $)=0$

${ }^{*} \mathrm{~F}$ 表面積 $\left(\pi r^{2}\right)$ 先発品と同様 $=1,20 \%$ 増又は減 $=0.5$

${ }^{*} \mathrm{G}$ 厚さ $(\mathrm{mm})$ 先発品と同様 $=1,20 \%$ 増又は減 $=0.5$

${ }^{*} \mathrm{H}$ 質量 $(\mathrm{mg})$ 先発品と同様 $=1,20 \%$ 増又は減 $=0.5$

「形状」や「色」は目視や IF で判別が容易であ るが「面積」,「厚さ」，「質量」に関しては IFで は情報を入手できるが，患者や薬片師が製剂を見 て客観的に評価するには難しい項目である。その 結果，先発医薬品との違いが割線の有無によって 分類された製剤はシロスタゾール，ノルフロキサ シン。刻印の裏の表示有無による違いにより分類
できた製剤はブロチゾラム， ロラタジン，アムロ ジピンやドネペジル (以上, 目視)。面積や質量 の違いで分類された製剤はクラリスロマイシンと なった（以上, IF)。レパミピド, チクロピジン, エナラプリル，アトルバスタチン製剤は分類への 決め手となる特徵を欠くことから, 先発医薬品と 後発医薬品の分類は困難であった。一方, トリア 
ゾラムは先発医薬品と後発医薬品の類似性はほと んど認められなかった（データは示していない）。

\section{2. クラスター分析 (ward 法) による分類と類 似性の検討}

分析例としてブロチゾラム (表 2)のクラスター 解析 ( ward 法) 結果のデンドログラム (図 1) を示 した．図1からブロチゾラム製剤 17 品目につい て平方距離が(1)の位置で切断すると日新製薬(株) の『ブロチゾラム錠 $0.25 \mathrm{mg}$ 』と先発医薬品であ るベーリンガー社の『レンドルミン錠 $0.25 \mathrm{mg} 』$ を含む後発医薬品に大きく 2 分類できた. さらに 平方距離が(2)の位置で評価すると, ベーリンガー 社の『レンドルミン錠 $0.25 \mathrm{mg} 』($ グループ A), さらに後発医薬品のうち『ゼストロミン錠（東和 薬品(株) )』『ブロチゾラム錠 $0.25 \mathrm{mg}$ 「タイヨー」

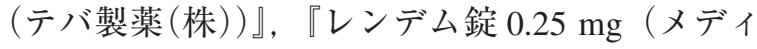
サ新薬(株) )』, 『ブロチゾラム錠 $0.25 \mathrm{mg} 「 \mathrm{YD} 」$ ((株) 陽進堂)』、『レドルパー錠 $0.25 \mathrm{mg}$ (大原薬 品工業(株))』,『ブロチゾラム錠 $0.25 \mathrm{mg}\lceil\mathrm{CH} 」$ (長 生堂製薬(株) )』、ソレントミン錠 $0.25 \mathrm{mg}$ (大正 薬品工業(株) )』, 『グッドミン錠 $0.25 \mathrm{mg}$ (田辺三 菱製薬(株) )』『ノクスタール錠 $0.25 \mathrm{mg}$ (アルフ レッサファーマ(株))』, 『ブロチゾラム錠 $0.25 \mathrm{mg}$

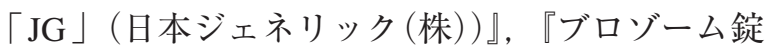
$0.25 \mathrm{mg}$ (ニプロファーマ(株))』のグループ (グ
ループ B ）と, 『ブロチゾラン錠 $0.25 \mathrm{mg}$ (日医 工(株))』,『ネストローム錠 $0.25 \mathrm{mg}$ (辰巳化学 (株) )』,『ロンフルマン錠 $0.25 \mathrm{mg}$ (共和薬品工業 (株))』, 『ブロメトン錠 $0.25 \mathrm{mg}$ (マイラン製薬 (株))』のグループ（グループC）および日新製

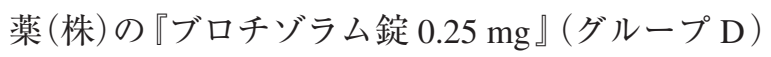
に分類された。すなわち平方距離が(2)の位置で評 価するとブロチゾラム製剤は 4 グループに分類さ れることが示された．また,デンドログラムより， 平方距離の分岐の高さで検討すると, 日新製薬

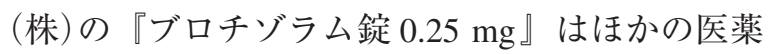
品と際立って大きく異なることが読み取れた。こ れは表 2 から, 『ブロチゾラム錠 $0.25 \mathrm{mg}$ のみ 割線を有しないこと，また錠剤の形が楕円である ことが強く影響していると考えられた。また，グ ループ B に属する錠剤間の平方距離の相違は 0 であり，これは今回の評価項目（表 2）において これら 11 製戍に違いがなかったことが反映され ている結果である。グループ C に属する 4 製郕 はデンドログラムの結果から,さらに 3 つのサブ グループに分類されることが示された（図 1).

同様の解析を行うことにより，レパミピド，エ ナラプリル，チクロピジンやアドルバスタチン製 剤は先発医薬品を含むグループに多くの後発医薬 品が分類され，それぞれの製郕に属する残りの後 発医薬品同士の類似性はほとんど見られなかっ

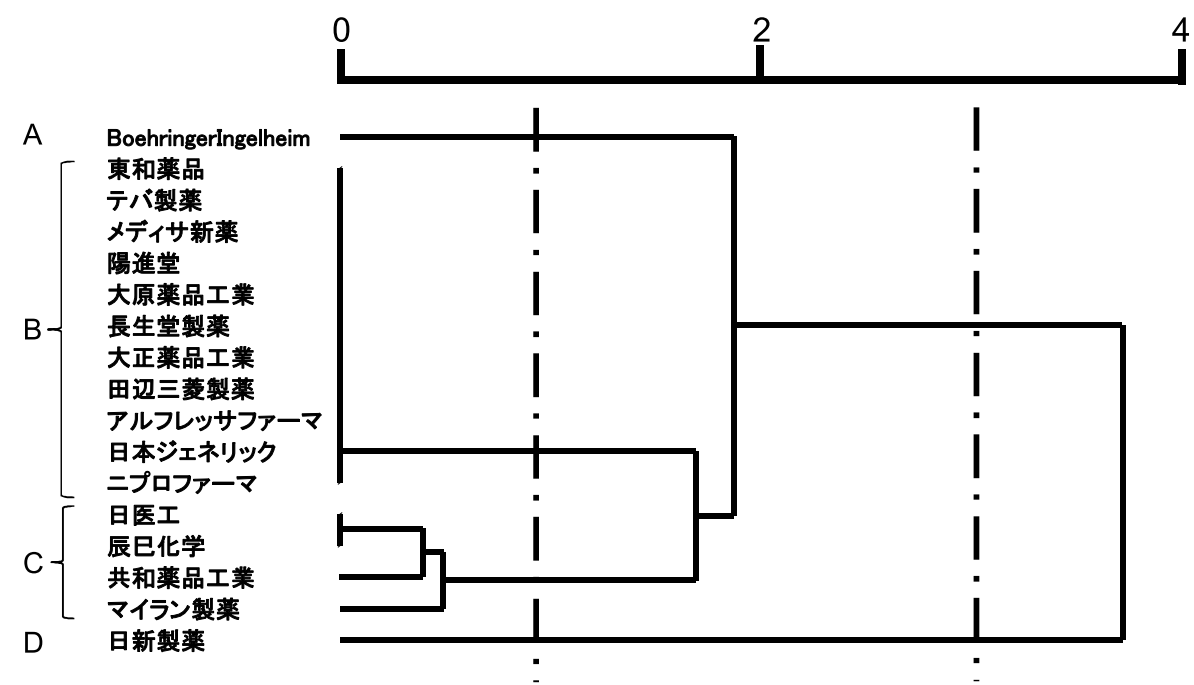

(2)

図 1 ブロチゾラム製剤のクラスター解析（Ward 法）によるデンドログラム 図中の(1)と(2)の平方距離は, それぞれ3，1の位置を示す. 
た.一方，トリアゾラムは 7 グループに分類され， 先発医薬品を含むグループに含まれる後発医薬品 も少なかった（図 2).

\section{3. 後発医薬品の先発医薬品との類似性の検討}

先発医薬品との類似性を見るため, 製剂ごとの 先発医薬品が含まれる群を「Aグループ」と定 義し（図 2), 医薬品全体に占める A グループの 医薬品数を図 3 に示した。レパミピド $(88 \%)$, エナラプリル $(88 \%)$,アドルバスタチン $(80 \%)$, ドネペジル $(72 \%)$ やチクロピジン $(70 \%)$ の 順で先発医薬品と類似性の高い後発医薬品が多く 供給されており，一方トリアゾラムは低かった $(15 \%)$.

\section{4. 各製薬会社での先発医薬品との類似率}

後発医薬品製薬会社 41 社が 12 成分を後発医薬 品として製造しているが，どの程度先発医薬品と 類似しているかについて検討した（図 4)。各後 発医薬品製造会社が発売している医薬品に占める

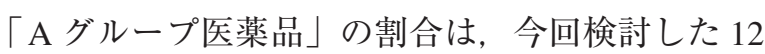
成分中, 日医工, 辰巳化学が 10 品目, 沢井製薬, 東和薬品が 9 品目と多いが, これら 4 社の先発医 薬品との類似率は平均 $61 \%$ であった。また，6品 目以上の後発医薬品を販売している製薬会社の平 均類似率は約 $51 \%$ であった。

\section{考察}

今回, 我々は先発医薬品と後発医薬品の外観上 の類似性を, 生物工学分野で遺伝子の類似性を判 定する際に沉用されているクラスター分析を用い て検討した。

今回クラスター解析を用いるにあたって, 著者 らの観点から錠剂の外観（形状，色，刻印，割線 の有無, 面積, 厚さ, 質量) 8 項目について重み 付けを検討しそれぞれ数值化した。項目数と種類 は分析者によって様々な值を取り得ることがで き，重み付けの最適化については今後の検討課題 であるが，必要な評価項目を選択したうえでクラ スター解析を行うことにより，これまで目視等の 主観に依っていた医薬品の外観上の違いを客観的
に記述できることが示された。

後発医薬品は先発医薬品に類似させて製造する ことで, 後発医薬品への処方変更時に調剂過誤の 防止やコンプライアンスの向上さらにはプラセボ 効果を期待するとの考えがあったのかもしれな い. ${ }^{5,6)}$ しかし, 後発医薬品市場へ多くの製薬会社 が参入し, また厚生労働省の「後発医薬品の安心 使用促進アクションプログラム」による数量シェ アの数值目標設定による使用量の増加により, 以 前からの外観類似による調剂ミスや服用ミスをさ らに複雑化しており, 渡辺らは先発医薬品と後発 医薬品の PTP外観類似性が服薬セイフティマネー ジメントに及ぼす影響を調査し, 医薬品の外観類 似性は調剤エラーに対して大きな影響を及ぼすこ

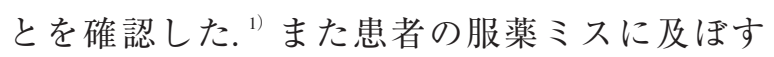
PTP 包装の外観類似性の危険性を再検証したとこ ろ，14\%の患者で包装類似が原因となった飲み間 違えを経験したとの報告がある.

こうした状況の下, 先発メーカーと同様に後発 医薬品メーカーも PTP 包装の外観や規格 - 含量 などの記載に配慮した製品化が行われているよう であるが，製品の剤型類似性を解析した報告はほ とんどないことから, 本研究では後発医薬品の形 状等の外観についてどの程度先発医薬品と類似し ているかをIFによる分類とクラスター分析によ り求め, 検討した。調査品目は 2011 年冬初収載 された脂質異常症治療薬, 抗認知症薬, 抗アレル ギー薬をはじめ既存収載品の抗菌薬, 降圧薬, 抗 血小板薬, 睡眠薬等である. 12 成分 219 品目に ついてIFによる 8 項目を調查した結果から，錠 剤の形状や色については殆どの後発医薬品が類似 していた。しかし, 刻印, 割線の有無, 面積, 厚 さ、質量ではそれぞれ異なるところも見られた(表 2)。IF を基にした分類では，「形状」「割線・刻 印の有無」「面積」「重量」のような明記されてい る項目を個々に比較は可能であるが, 総合的な比 較やサブグループ分けの解析は不可能であった. そこでこれらの点を克服する手法として, IFか ら得られた結果を数值化して類似性をクラスター 分析（Ward 法）によって客観的に評価すること を試みた。

その結果，IFを基にしたヒトによる分類では, 

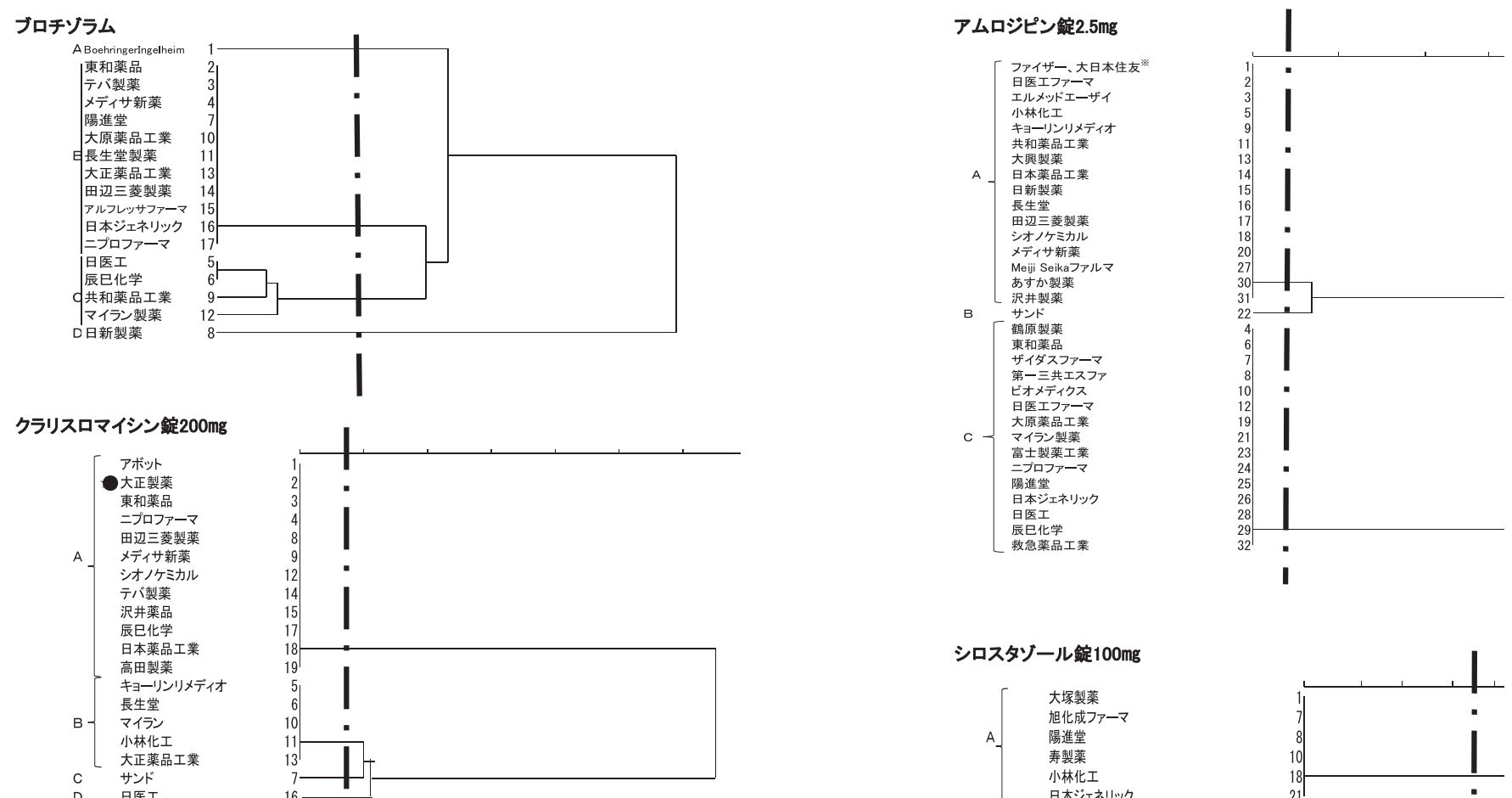

シロスタゾール錠100mg
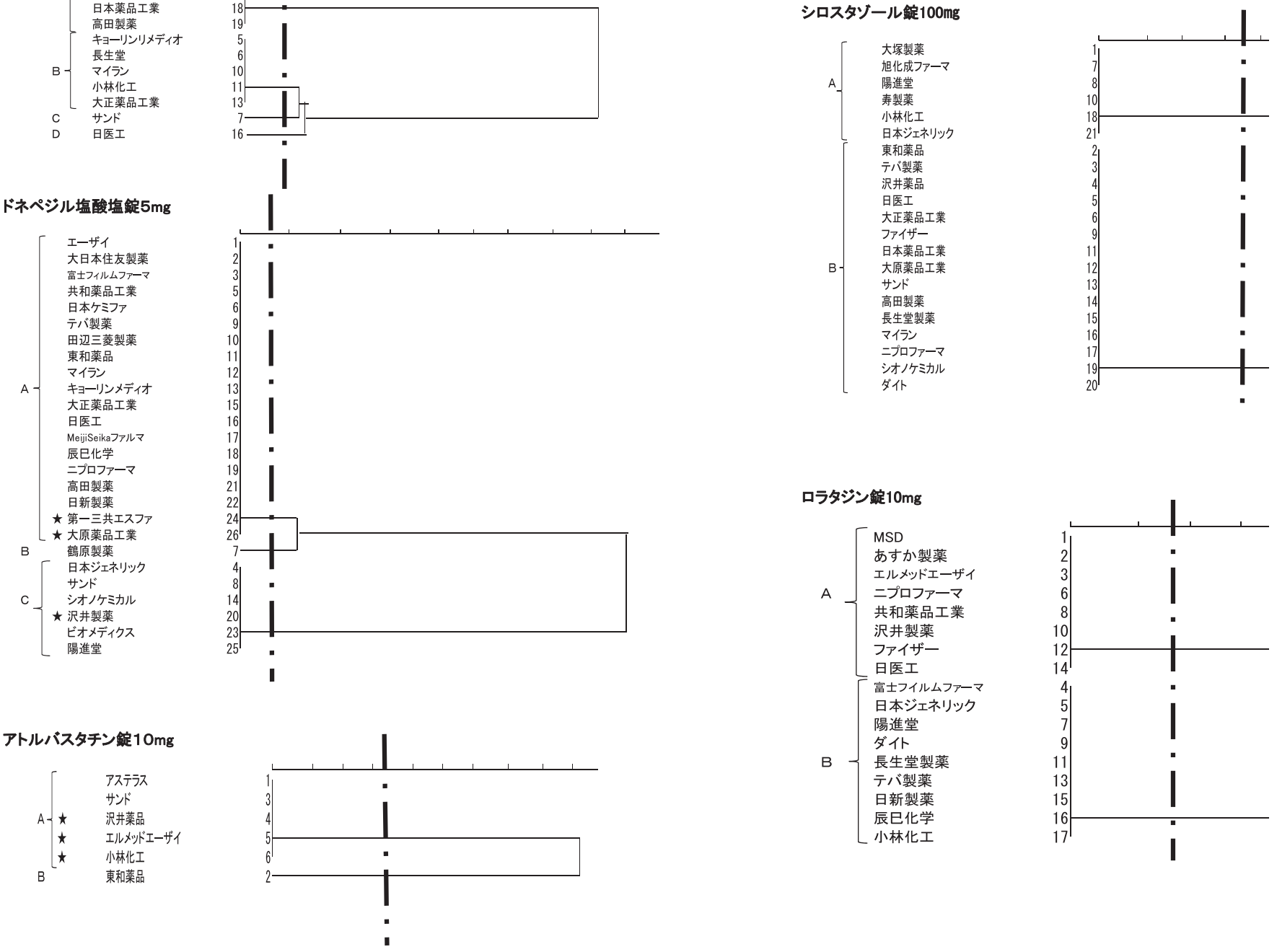

図 211 種類の薬剤のクラスター解析（Ward 法）によるデンドログラム

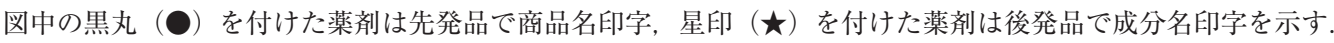
横軸は平方距離を示し, 各薬剤は平方距離が 1 点破線の位置で評価を行った. 

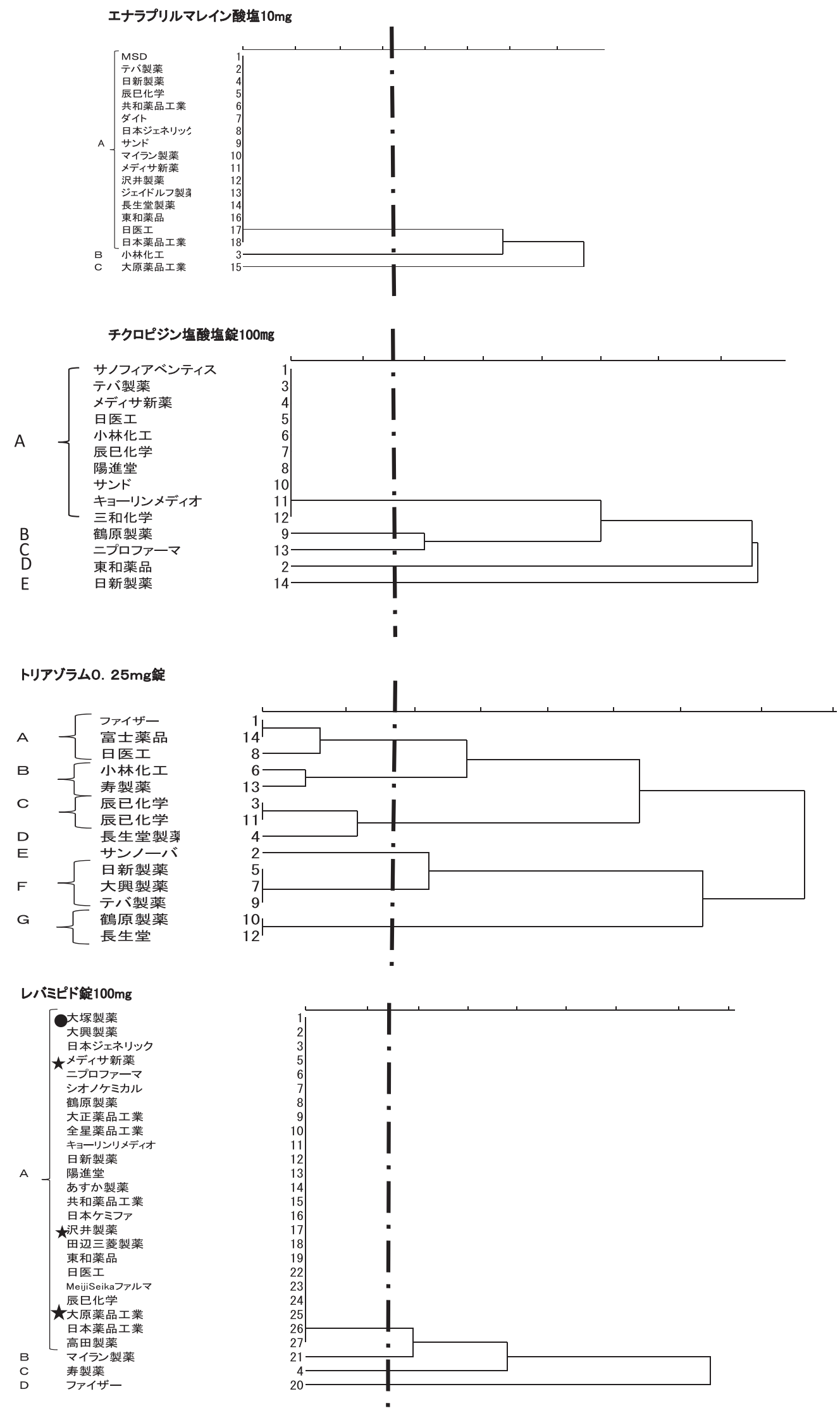


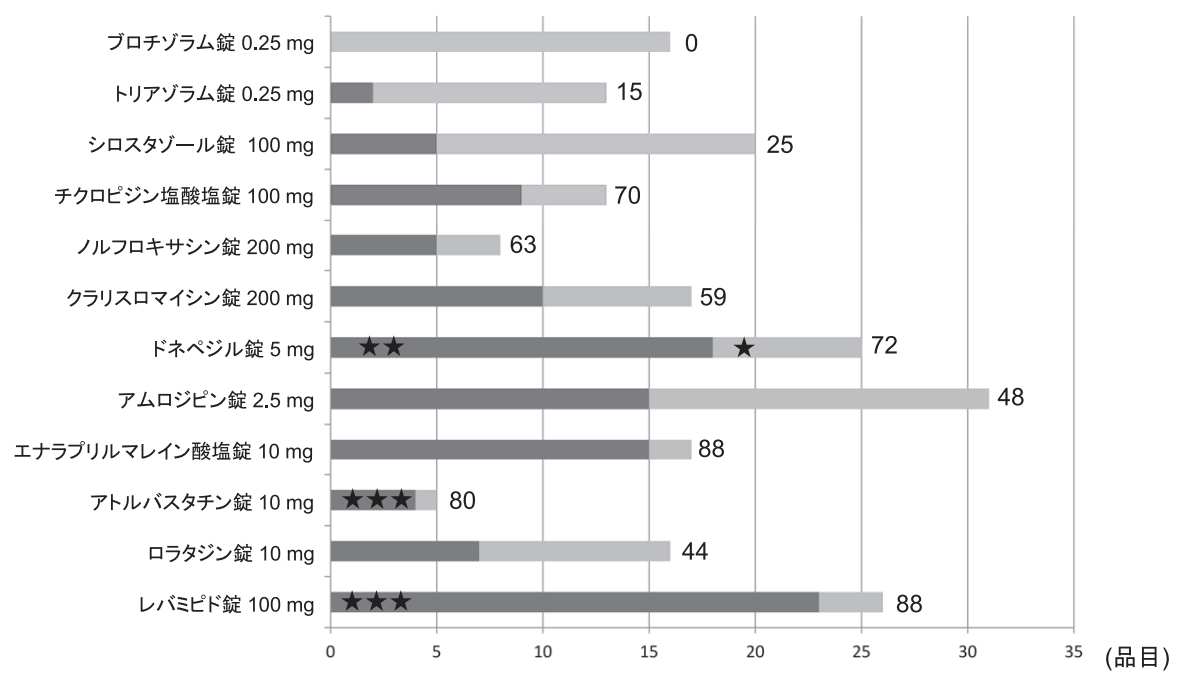

図 3 製剤毎の先発品と後発品の類似性

濃い網掛けは, 各製剤中の先発品が含まれるグループ（Aグループ）に属する品目数, 薄い網掛けは全品目数 ( A グループを含む)を示す. 横棒グラフ右端の数字は, 全品目数中の A グループ品目数の百分率（\%）を示す. なお，棒グラフ中の星印（ネ）は成分名印字を示す.

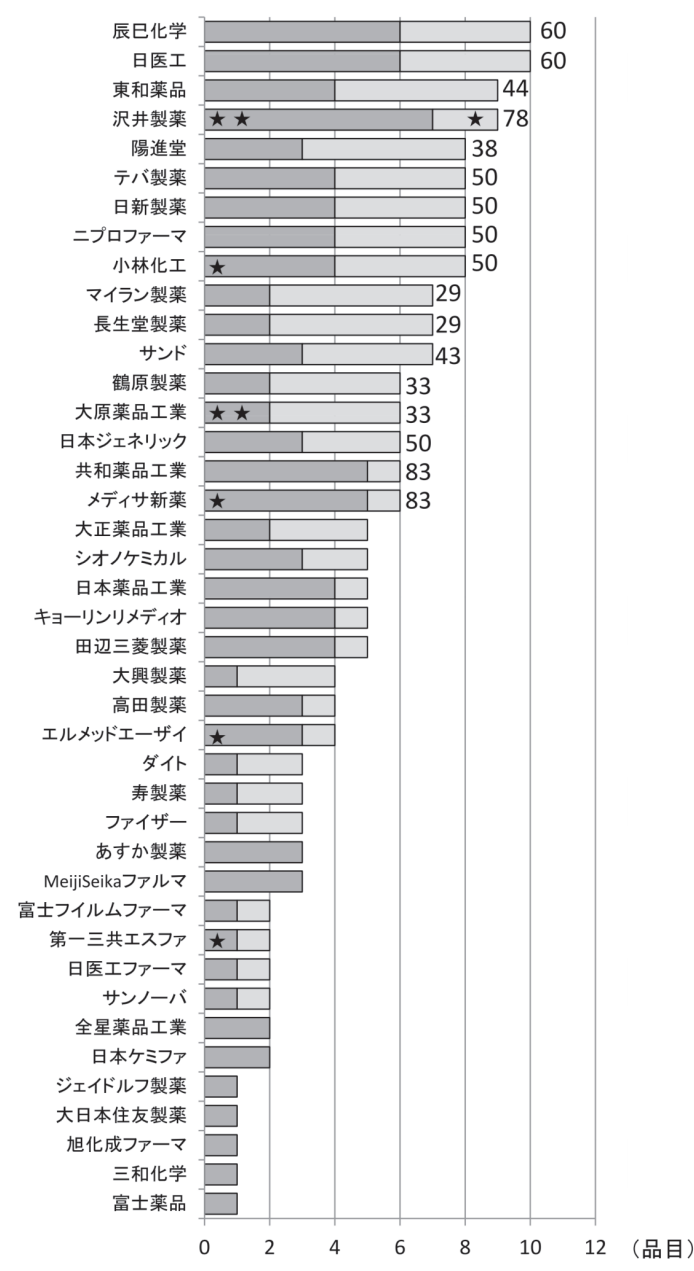

図 4 メーカー毎の先発品と後発品の類似性 濃い網掛けは, 各製剤中の先発品が含まれるグループ (Aグループ) に属する品目数, 薄い網掛けは全品目数 (Aグループを含む)を示す. 横棒グラフ右端の数字は, 上位 16 社における, 全品目数中の $\mathrm{A}$ グループ品目数の百分率 (\%) を示す.

な挍，棒グラフ中の星印（れ）は成分名印字を示す.
総合的な類似性の比較のみならず，不可能であっ たサブグループ解析についても図 2 に示すよう に類似性をデンドログラムによって表記できる可 能性が示された。

この解析から, 同一薬効成分の医薬品であって も後発医薬品の多くが先発医薬品と同じグループ （グループA）に集約されるレパミピド，エナラ プリル，アドルバスタチンやチクロピジンと， ト リアゾラムのように 7 グループに細分されて錠剤 間の類似性にそしい製品というょうに, 薬効分類 そのものが共通の剂形類似性を示すという傾向は 見られないこと（図3），また，各製薬会社での 先発医薬品との類似性については 6 品目以上の後 発医薬品を製造している製薬会社の平均類似率は 約 $51 \%$ で, 同一会社内に扔いて先発医薬品との 類似性を高める強い意図は読み取れないことなど (図 4), 多数の後発医薬品を様々な視点で分類で きる可能性も示すことができた.

厚生労働省は平成 24 年度診療報酬改定におけ る環境整備で, 後発医薬品調剂体制加算の見直し, 薬剂情報提供文書を活用した後発医薬品に関する 情報提供, 医療機関における後発医薬品を積極的 に使用する体制の評価, 一般名処方の推進, 処方 せん様式の変更を通じ, 後発医薬品使用の普及に 対し後押しを進めていることから, 今後, 各施設 において後発医薬品の採用が一層進むことは想像 
に難くない.

近年, 先発医薬品には製品名がカプセル剤や フィルムコーティング錠に直接印字された製品が 見受けられるが，今回の調查でも先発医薬品のク ラリスロマイシンとドネペジルに商品名が印字さ れていた。 2011 年に新収載されたレパミピド, アドルバスタチンやドネペジルには成分名の印字 が9品目に見られた（図3）。また図4では 6 社 9 品目に成分名の印字が見られた。園田は製品名 表示に対して「1 回量包装の際の錠剂鑑別が確実・ 効率的にできる」,「患者さんの服薬コンプライア ンス向上が期待できる」など，評価は極めて高い と述べている. ${ }^{7)}$ 今後急速に普及する後発医薬品 の差別化には，この 3 成分のように製品に成分名 等を印字することも重要な要素と考えられる.

ところで後発医薬品を導入する場合に, 薬剤師 をはじめ医療従事者は外観が類似している医薬品 よりも識別性の高い医薬品が取り違え等のリスク 面での医療安全に貢献すると考えているが，患者 からはその逆も考えられる. 60 歳代以上の患者 の多くは服用時に医薬品を「医薬品本体の外観の み」で識別するとの報告があり, 先発医薬品から 後発医薬品への変更の場合には類似医薬品を選択 したほうが患者の理解が得やすく服用ミスにも繋 がらないと考えられる。このことは，中央社会保 険医療協議会がまとめた平成 22 年度の「後発医 薬品の使用状況調査」の調查で, 後発医薬品につ いての説明を行ったにもかかわらず患者が後発医 薬品の使用を希望しなかった理由として,「これ まで使っていた薬（ラベルの色や剤形など）を変 えることに抵抗があったから」という項目が最多

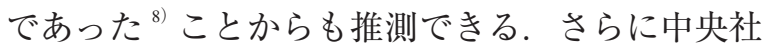
会保険医療協議会がまとめた平成 21 年度の「後 発医薬品の使用状況調査」によると, 後発医薬品 への切り替えが難しいケースとして『精神科の薬 剤は，後発医薬品に切り替える際，形状や色の問
題がある』ことが報告されていることから, 9) 特 に精神科で使用頻度の高い医薬品を後発医薬品に 変更する場合の指標として，ここで紹介したクラ スター分析で形状や色に重みを置いた客観的な類 似性の指標が有効になると考えられる。

以上，今回の報告では上市されている先発医薬 品と後発医薬品に対しクラスター解析により剤形 類似性が総合的に示されることを明らかとし，ま たその利用可能性について推定した。

\section{引用文献}

1）渡辺洋子, 佐藤弘希, 皆川淑哉, 月岡良太, 杉山 康浩, 岡山善郎, 異島 優, 渡邊博志, 門 大介, 安楽 誠, 丸山 徹, 先発および後発医薬品の外 観類似性が服薬セイフティマネージメントに及 ぼす影響, 医療薬学, 2012, 38, 18-24.

2）厚生労働省医薬食品局安全対策課長通知, “医 療用医薬品のバーコード表示の実施要項につい て”, 薬食安発第0915001号 (2006年18年9月15日).

3）大高聡也, クラスター分析を用いた配電用変電 所のグループ化に関する研究, ASTE, 2003, 11, 1-3.

4）能美 誠, クラスター分析を応用した隣接型地 域区分法の開発, 農村計画学雑誌, 1997, 16, 228239.

5）沼田 稔, 医薬ジャーナル壇, 2011, 47, 2229-2231.

6) Greene JA, Kesselheim AS, Why do the same drugs look different? Pills, trade dress, and public health, The New England Journal of Medicine, 2011, 365, 83-89.

7）園田 努, 高齢者にやさしい医薬品包装・容器 の開発の現状, 月刊薬事, 2011, 53, 539-549.

8）中央社会保険医療協議会資料, 診療報酬改定の 結果検証に係る特別調查（平成22年度調查） 2011年9月7日, p.32.

9）中央社会保険医療協議会資料, 診療報酬改定の 結果検証に係る特別調查（平成21年度調查） 2010年5月26日, p.107. 